\title{
Correction to: Comparison of hepatitis B vaccine efficacy in Japanese students: a retrospective study
}

\author{
Masanori Ogawa ${ }^{1 *}$, Dai Akine ${ }^{1}$ and Teppei Sasahara ${ }^{2}$
}

Correction to: Environ Health Prev Med (2019) 24:80

https://doi.org/10.1186/s12199-019-0837-1

Following publication of the original article [1], the authors spotted an error in their paper concerning the positive rate in the right side in Table 2.

That is, 89.7 not 89., 93.5 not 93., 56.7 not 56., 75.3 not 75. and 94.0 not 94 .

The original article has been corrected. The correct presentation of Table 2 is shown below.

\section{Author details}

${ }^{1}$ Health Service Center, Jichi Medical University, 3311-1, Yakushiji, Shimotsuke 329-0498, Japan. ²Division of Clinical Infectious Diseases, Department of Infection and Immunity, Jichi Medical University, 3311-1, Yakushiji,

Shimotsuke 329-0498, Japan.

Published online: 03 February 2020

\section{Reference}

1. Ogawa M, et al. Comparison of hepatitis B vaccine efficacy in Japanese students: a retrospective study. Environ Health Prev Med. 2019;24:80 https:// doi.org/10.1186/s12199-019-0837-1.

Full list of author information is available at the end of the article 
Table 2 Positive rate of HBs antibody after HB vaccination

\begin{tabular}{|c|c|c|c|c|c|c|c|c|c|c|c|c|}
\hline \multirow{2}{*}{$\begin{array}{l}\text { Vaccine } \\
\text { Administration route }\end{array}$} & \multirow{2}{*}{$\begin{array}{l}\text { Total } \\
\text { number }\end{array}$} & \multirow{2}{*}{$\begin{array}{l}\text { Age range, } \\
\text { median (IQR) }\end{array}$} & \multicolumn{3}{|l|}{ HBs antibody } & \multirow{2}{*}{$\begin{array}{l}\text { Positive } \\
\text { rate (\%) }\end{array}$} & \multirow[t]{2}{*}{ Sex } & \multirow{2}{*}{$\begin{array}{l}\text { Total } \\
\text { number }\end{array}$} & \multirow{2}{*}{$\begin{array}{l}\text { Age range, } \\
\text { median (IQR) }\end{array}$} & \multicolumn{2}{|c|}{ HBs antibody } & \multirow{2}{*}{$\begin{array}{l}\text { Positive } \\
\text { rate (\%) }\end{array}$} \\
\hline & & & Median (IQR) & $(+)$ & $\overline{(-)}$ & & & & & $\overline{(+)}$ & $(-)$ & \\
\hline \multirow[t]{2}{*}{ Bimmugen $^{\oplus}$ subcutaneous } & 514 & $\begin{array}{c}19-25 \\
20(19-21)\end{array}$ & $\begin{array}{l}84.9(34.5-217) \\
\mathrm{mlU} / \mathrm{mL}\end{array}$ & 473 & 41 & $92.0^{*}$ & Men & 204 & $\begin{array}{l}19-25 \\
20(19-21)\end{array}$ & 183 & 21 & $89.7^{\dagger}$ \\
\hline & & & & & & & Women & 310 & $\begin{array}{l}19-22, \\
19(19-19)\end{array}$ & 290 & 20 & $93.5^{\neq}$ \\
\hline \multirow[t]{2}{*}{ Heptavax-\|® ${ }^{\circledast}$ subcutaneous } & 373 & $\begin{array}{c}19-30 \\
20(19-21)\end{array}$ & $\begin{array}{l}28.7(5-216) \\
\mathrm{mlU} / \mathrm{mL}\end{array}$ & 248 & 125 & $66.3^{*}$ & Men & 180 & $\begin{array}{l}19-30 \\
20(19-21)\end{array}$ & 102 & 72 & $56.7^{\dagger}$ \\
\hline & & & & & & & Women & 193 & $\begin{array}{l}19-22, \\
19(19-19)\end{array}$ & 146 & 47 & $75.3^{\ddagger}$ \\
\hline \multirow[t]{2}{*}{ Heptavax-II® intramuscular } & 247 & $\begin{array}{c}19-27 \\
20(19-21)\end{array}$ & $\begin{array}{l}190 \text { (41.6-534) } \\
\mathrm{mlU} / \mathrm{mL}\end{array}$ & 220 & 27 & $89.1^{*}$ & Men & 97 & $\begin{array}{l}19-27 \\
20(19-21)\end{array}$ & 79 & 18 & $81.4^{+}$ \\
\hline & & & & & & & Women & 150 & $\begin{array}{l}19-22 \\
19(19-20)\end{array}$ & 141 & 9 & $94.0^{\ddagger}$ \\
\hline
\end{tabular}

\footnotetext{
${ }^{*}$ There was a significant difference among the Bimmugen ${ }^{\oplus}$ subcutaneous, Heptavax- $-I^{\oplus}$ subcutaneous, and Heptavax- $I I^{\oplus}$ intramuscular groups $(p<0.05)$

$t, \neq$ There were significant differences among the Bimmugen ${ }^{\oplus}$ subcutaneous, Heptavax- $-I^{\circledast}$ subcutaneous, and Heptavax- $\|{ }^{\oplus}$ intramuscular groups in both men and women $(p<0.05)$
} 